\title{
Stress and quality of sleep in undergraduate nursing students
}

\author{
Estresse e qualidade do sono em alunos de graduação em enfermagem \\ Estrés y calidad de sueño en estudiantes de grado en enfermería
}

Kézia Katiane Medeiros da Silva' ORCID: 0000-0002-5782-9595

Milva Maria Figueiredo de Martino ORCID: 0000-0002-3877-4218

Clarissa Maria Bandeira Bezerra" ORCID: 0000-0001-9872-4952

Ângela Monic Lima de Souza" ORCID: 0000-0003-2037-3608

Danila Maria da Silva" ORCID: 0000-0003-3833-6389

Jacqueline Targino Nunes" ORCID: 0000-0003-1002-1246

'Universidade Federal de São Paulo. São Paulo, São Paulo, Brazil. "Universidade Federal do Rio Grande do Norte. Natal, Rio Grande do Norte, Brazil.

How to cite this article: Silva KKM, Martino MMF, Bezerra CMB, Souza AML, Silva DM, Nunes JT. Stress and quality of sleep in undergraduate nursing students.

Rev Bras Enferm. 2020;73(Suppl 1):e20180227. doi: http://dx.doi.org/10.1590/0034-7167-2018-0227

\section{Corresponding author:}

Kézia Katiane Medeiros da Silva

E-mail: kezia_taty@hotmail.com

EDITOR IN CHIEF: Dulce Aparecida Barbosa ASSOCIATE EDITOR: Dalvani Marques

\section{ABSTRACT}

Objective: to analyze the level of stress and sleep quality in nursing students according to terms of the nursing program. Method: descriptive and cross-sectional research developed in a higher education institution in Northeastern Brazil on 167 students. We used data collection, sociodemographic information, and a scale for assessing stress and sleep quality in nursing students. Results: we identified a statistically significant difference between domains of the stress scale and the terms of the undergraduate program, and between the quality of sleep and such terms such as as in the fourth and sixth semesters. Conclusion: different stress scores show that the semester which concerns students the most is the fifth. Quality of sleep was deemed good for the first, third, fifth, seventh, and eighth semesters; and poor for the fourth and sixth terms.

Descriptors: Stress; Sleep; Students; Nursing; Sleep Deprivation.

\section{RESUMO}

Objetivo: analisar o nível de estresse e a qualidade do sono em estudantes de enfermagem por períodos do curso. Método: pesquisa descritiva e transversal desenvolvida em uma instituição de ensino superior do Nordeste brasileiro com 167 estudantes. Utilizaramse, para coleta de dados, informações sociodemográficas e uma escala de avaliação do estresse e qualidade do sono em estudantes de enfermagem. Resultados: identificou-se diferença estatística significante entre os domínios da escala de estresse e os períodos do curso de graduação, e entre a qualidade do sono e os períodos do curso, como no quarto e sexto períodos. Conclusão: os diferentes escores do estresse demonstram que o semestre do estudante que mais o preocupa é o quinto. A qualidade de sono mostrou-se de boa qualidade para o primeiro, terceiro, quinto, sétimo e oitavo períodos; e qualidade ruim de sono para o quarto e sexto períodos.

Descritores: Estresse; Sono; Estudantes; Enfermagem; Privação do Sono.

\section{RESUMEN}

Objetivo: evaluar el nivel de estrés y la calidad de sueño en estudiantes de enfermería durante los períodos de la carrera. Método: investigación descriptiva y transversal realizada con 167 estudiantes de una institución de enseñanza superior del Nordeste brasileño. En la recolección de datos se utilizaron informaciones sociodemográficas y una escala de evaluación de estrés y calidad de sueño en estudiantes de enfermería. Resultados: se identificó una diferencia estadística significativa entre los aspectos de la escala de estrés y los períodos de la carrera de grado, y entre la calidad de sueño y los períodos de la carrera, como en el cuarto período y en el sexto período. Conclusión: los diferentes puntajes de estrés demuestran que el semestre que más le había preocupado al estudiante fue el quinto semestre. Se encontró una buena calidad de sueño en el primer, el tercer, el quinto, el séptimo y el octavo períodos; y se encontró una mala calidad de sueño en el cuarto período y en el sexto período.

Descriptores: Estrés; Sueño; Estudiantes; Enfermería; Privación de Sueño. 


\section{INTRODUCTION}

Interactions established between students and study conditions at the university can compromise their mental and psychological health. These interactions comprise the autonomy of the student in relation to tasks, the degree of satisfaction to perform work activities, perspectives, and the established human relationships. In addition to these aspects, the content of the tasks are factors that may contribute to students' mental distress ${ }^{(1)}$.

University students are often subjected to irregular study schedules due to the load of tasks required in university programs, often study in the daytime, but extend it to the nighttime in order to accomplish all the tasks and study for tests ${ }^{(2)}$.

The need to fulfill these commitments compromises sleep, causes daytime sleepiness, and increases the risk of alterations in health ${ }^{(2)}$. These subjects are exposed to environmental-related stressors, such as distances between the school and the family environment, and organizational-related stressors such as course load and the schedule of classes and study ${ }^{(3)}$.

Students, when graduating from high school and entering the university, may present several difficulties such as the provision of their own food, new social relationships, consumption of fast-foods, psychosocial instability, stress caused by several factors and sociodemographic characteristics, and changes in the sleep quality ${ }^{(4)}$.

Authors of some research have aimed to examine the dominant style of coping with stress in nursing students, their relationships with stressful life events, personality traits and mood swings during the academic education. Results showed that the dominant style of coping in the students was found in significant correlations between emotional coping and neurotic trait ${ }^{(5)}$.

Conditions in higher education can lead undergraduate students to the adoption of inadequate lifestyles, such as alcohol and tobacco consumption, besides sedentary lifestyle ${ }^{(6)}$. Among stressors in the university, we highlight the increase in responsibility, anxiety, competitiveness, academic tasks, financial difficulties and, mainly, professional choice.

Freshman students are subject to distinct emotional issues that affect their feelings and behaviors related to their daily functioning, including the health status ${ }^{(7)}$.

\section{OBJECTIVE}

To analyze the level of stress and sleep quality in nursing students according to terms of the nursing program.

\section{METHOD}

\section{Ethical aspects}

All participants signed the informed consent form part of Resolution no. 466/12 of the Brazilian Ministry of Health. Ethical aspects were respected according to the norms of the Research Ethics Committee of the Federal University of Rio Grande do Norte, approved and registered with Opinion no. $751,589^{(8)}$.

\section{Study design, location, and period}

The research is characterized as a descriptive, cross-sectional study with a quantitative approach. The study was developed at a nursing higher education institution in Natal, Rio Grande do Norte, Brazil, on undergraduate nursing students from the first to the ninth semester of the program.

\section{Population or sample, inclusion and exclusion criteria}

The population consisted of 235 students. The choice was consecutive, that is, all students who were in the classroom during data collection were invited to participate and respond to the instruments. However, students of the second and ninth semesters were not found to fill out the questionnaires, since those of the second term attended classes in other centers and departments other than nursing, and those of the ninth were interns in hospital units. The latter, because of the proximity of the end of the program, had no more on-site classes at the university.

Thus, were included all students of both sexes, regularly enrolled in the first, third, fourth, fifth, sixth, seventh, and eighth semesters who agreed to participate by signing the informed consent form. Students of the second and ninth terms $(n=60)$, students on medical or maternity leave $(n=3)$, and those who did not return the questionnaires used in the study within the period determined by the researcher $(n=4)$ were excluded. Thus, the sample consisted of 168 students, in the period from September 2015 to April 2016.

\section{Study protocol}

Regarding the procedure, the collection was arranged before the beginning of the classes, with previous authorization of the professor of the subject. Evaluators handed out the instruments to the participants and the students returned the questionnaires immediately after the completion.

The instruments used for data collection were as follows: individual and sociodemographic characterization questionnaire; Pittsburgh Sleep Quality Index questionnaire (PSQI); and an instrument for assessing stress in nursing students (Avaliação de Estresse em Estudantes de Enfermagem - AEEE). The individual and sociodemographic characterization questionnaire consists of 23 items to characterize individual and sociodemographic data of the students (educational institution, age, sex, children, and marital status); professional experience (if the student works); means of locomotion to the university (if they have their own vehicle); lifestyle habits with frequency options (physical activity, leisure or social activities, consumption of alcoholic beverages, whether they are smokers, use of some kind of drug, sleeping medications, whether they have insomnia); and whether the subject has any disease.

The PSQI questionnaire, validated by Buysse ${ }^{(9)}$, is self-applicable and is intended to evaluate the characteristics of sleep patterns and quantify the quality of sleep of individuals. It comprises the subjective quality and the occurrence of sleep disorders with an interval prior to the date of its completion, which can be determined by the researcher ${ }^{(10)}$. Validated in Brazil(11), this 
questionnaire has ten questions, arranged in seven domains, which can be attributed from zero to three points. The total sum can reach 21 points, and scores higher than five indicate a poor pattern of sleep quality ${ }^{(9-10)}$.

The PSQI is composed of seven domains: the first refers to the subjective quality of sleep, considering the individual perception regarding the quality of sleep; the second refers to sleep latency and the time required to begin sleep; the third refers to the duration of sleep, considering how long the individual remains asleep; the fourth domain refers to the usual sleep efficiency obtained through the relationship between the number of asleep hours and the number of hours remaining in the bed, not necessarily sleeping; the fifth refers to sleep disorders, indicating the presence of situations that compromise the sleeping hours; the sixth refers to the use or not of sleeping medications; and the seventh refers to daytime sleepiness and disturbances during the day, in addition to changes in disposition and enthusiasm to perform routine activities ${ }^{(11)}$.

The AEEE instrument was created based on the items of the Student Nurse Stress Index (SNSI) consisting of 30 items, grouped in six domains: performing practical activities; professional communication; time management; environment; professional training; theoretical activity ${ }^{(12)}$. Each item of the scale depicts a possible situation of experiencing stress, answered by a four-point Likert scale, varying from zero to three, in terms of intensity for the scores of each domain: low stress level (0), moderate (1), high (2), and very high (3). The instrument could be used to assess the intensity of stressors among nursing students. For this verification, the average of the elements of each domain of higher and lower stress per student was estimated.

\section{Analysis of results and statistics}

Results were analyzed in descriptive statistics using means, standard deviation, and frequency. Multiple association tests (Chi-square or Fisher's exact, Mann-Whitney test, Kruskal-Wallis test) were used to compare stress and sleep-quality domains with sociodemographic variables. In all analyses, a $5 \%$ level of significance was considered for the statistically significant result $(p<0.05)$.

\section{RESULTS}

In Table 1 we show the sociodemographic characteristics of the students in numerical and percentage values. We observed that $90.41 \%$ are women and $9.58 \%$ are men. Of these, $93.41 \%$ of the students reported not working, only studying, and $6.58 \%$ revealed having to administer employment and study.

The distribution of stress levels and terms of the nursing program are described in Table 2 as numerical values and percentages. We perceived that students of the fifth and eighth semesters presented average levels of stress, respectively, $10.8 \%$ and $6.6 \%$. The sixth term consisted of the majority of students, with high stress level (4.2\%).

In Table 3 we describe the distribution of averages and standard deviation of Norte, Brazil, 2016 the domains per semesters applied to the sample. The KruskalWallis test determined a significant $p$-value regarding semesters of the program in four domains: the first - performing practical activities $(p<0.0001)$; the second - professional communication $(p<0 ; 0001)$; the fifth - professional training $(p<0.0001)$; and the sixth - theoretical activity $(p=0.0107)$. The first domain had the highest average for performing practical activities in the sixth term (12.35), and the lowest value was in the second domain professional communication (3.20) - in the first semester.

We demonstrate the PSQI classification in Table 4, divided into numerical and percentage values. Poor classification was obtained in the fourth semester, with $73.33 \%$ of the students, and in the sixth semester, with $78.26 \%$. The $p$-value was statistically significant for the PSQI classifications between the program semesters with the $p<0.0001$ by the Chi-square test, and we observed poor quality of sleep between students of the forth and sixth terms.

Table 1 - Distribution of the sample regarding sociodemographic characteristics of the studied population, Natal, Rio Grande do Norte, Brazil, 2016

\begin{tabular}{llc}
\hline Variáveis & & $\mathbf{n}(\mathbf{\%})$ \\
\hline Sex & Wen & $16(9.58)$ \\
Marital status & Somen & $151(90.41)$ \\
& Married & $156(93.41)$ \\
Children & Other & $7(4.19)$ \\
& Yes & $5(2.39)$ \\
Have a job & No & $162(97.00)$ \\
& Yes & $11(6.58)$ \\
Usually drink coffee or tea & No & $156(93.41)$ \\
& Yes & $110(65.86)$ \\
Use of sleeping medications & No & $57(34.13)$ \\
& Yes & $16(9.58)$ \\
Consumption of alcoholic beverages to sleep & Yes & $150(89.82)$ \\
& No & $1(0.59)$ \\
Use of medications in general & Yes & $121(72.45)$ \\
& No & $19(11.37)$ \\
Socially drink alcoholic beverages & Yes & $122(73.62)$ \\
Have your own vehicle & No & $45(26.94)$ \\
& Yes & $28(16.76)$ \\
Engage in physical activity & No & $139(83.23)$ \\
& Yes & $76(45.50)$ \\
& No & $90(53.89)$ \\
& Sometimes & $1(0.59)$ \\
\hline
\end{tabular}

Table 2 - Distribution of stress levels and terms of the nursing program, Natal, Rio Grande do

\begin{tabular}{lcccccccc}
\hline $\begin{array}{l}\text { Stress } \\
\text { levels }\end{array}$ & $\begin{array}{c}\mathbf{1}^{\text {st }} \text { term } \\
\mathbf{n}(\%)\end{array}$ & $\begin{array}{c}\mathbf{3}^{\text {rd }} \text { term } \\
\mathbf{n}(\%)\end{array}$ & $\begin{array}{c}\mathbf{4}^{\text {th }} \text { term } \\
\mathbf{n}(\%)\end{array}$ & $\begin{array}{c}\mathbf{5}^{\text {th }} \text { term } \\
\mathbf{n}(\%)\end{array}$ & $\begin{array}{c}\mathbf{6}^{\text {th }} \text { term } \\
\mathbf{n}(\%)\end{array}$ & $\begin{array}{c}\mathbf{7}^{\text {th }} \text { term } \\
\mathbf{n}(\%)\end{array}$ & $\begin{array}{c}\mathbf{8}^{\text {th }} \text { term } \\
\mathbf{n}(\%)\end{array}$ & $\begin{array}{c}\text { Total } \\
\mathbf{n}(\%)\end{array}$ \\
\hline Low & $13(7.8)$ & $11(6.6)$ & $11(6.6)$ & $13(7.8)$ & $4(2.4)$ & $9(5.4)$ & $7(4.2)$ & $68(40.7)$ \\
Moderate & $5(3.0)$ & $3(1.8)$ & $9(5.4)$ & $18(10.8)$ & $6(3.6)$ & $4(2.4)$ & $11(6.6)$ & $56(33.5)$ \\
High & $2(1.2)$ & $1(0.6)$ & $4(2.4)$ & $4(2.4)$ & $7(4.2)$ & $2(1.2)$ & $2(1.2)$ & $22(13.2)$ \\
Very high & $0(0.0)$ & $0(0.0)$ & $6(3.6)$ & $4(2.4)$ & $6(3.6)$ & $3(1.8)$ & $2(1.2)$ & $21(12.6)$ \\
Total & $20(1.0)$ & $15(9.0)$ & $30(18.0)$ & $39(23.4)$ & $23(13.8)$ & $18(10.8)$ & $22(13.2)$ & $167(100)$
\end{tabular}


Table 3 - Distribution of averages and standard deviation of the domains per semesters applied to the sample, Natal, Rio Grande do Norte, Brazil, 2016

\begin{tabular}{|c|c|c|c|c|c|}
\hline Variable & Semester & $\mathbf{n}$ & Average & $\begin{array}{l}\text { Standard } \\
\text { deviation }\end{array}$ & $p$ value \\
\hline \multirow{7}{*}{$\begin{array}{l}\text { Domain 1: } \\
\text { Performing } \\
\text { practical } \\
\text { activities }\end{array}$} & 1 & 20 & 6.65 & 4.23 & \multirow{7}{*}{$<0.0001$} \\
\hline & 3 & 15 & 7.47 & 3.52 & \\
\hline & 4 & 30 & 11.07 & 3.31 & \\
\hline & 5 & 39 & 10.79 & 2.44 & \\
\hline & 6 & 23 & 12.35 & 2.98 & \\
\hline & 7 & 18 & 10.11 & 3.60 & \\
\hline & 8 & 22 & 10.68 & 2.61 & \\
\hline \multirow{7}{*}{$\begin{array}{l}\text { Domain 2: } \\
\text { Professional } \\
\text { communication }\end{array}$} & 1 & 20 & 3.20 & 2.53 & \multirow{7}{*}{$<0.0001$} \\
\hline & 3 & 15 & 3.67 & 2.92 & \\
\hline & 4 & 30 & 5.63 & 2.86 & \\
\hline & 5 & 39 & 6.23 & 2.21 & \\
\hline & 6 & 23 & 6.13 & 2.30 & \\
\hline & 7 & 18 & 6.89 & 2.32 & \\
\hline & 8 & 22 & 6.18 & 1.56 & \\
\hline \multirow{7}{*}{$\begin{array}{l}\text { Domain 3:Time } \\
\text { management }\end{array}$} & 1 & 20 & 9.20 & 3.27 & \multirow{7}{*}{0.1133} \\
\hline & 3 & 15 & 11.07 & 1.39 & \\
\hline & 4 & 30 & 10.70 & 2.34 & \\
\hline & 5 & 39 & 10.03 & 2.85 & \\
\hline & 6 & 23 & 11.70 & 2.20 & \\
\hline & 7 & 18 & 10.56 & 3.76 & \\
\hline & 8 & 22 & 10.91 & 2.79 & \\
\hline \multirow{7}{*}{$\begin{array}{l}\text { Domain 4: } \\
\text { Environment }\end{array}$} & 1 & 20 & 7.20 & 2.65 & \multirow{7}{*}{0.1389} \\
\hline & 3 & 15 & 6.87 & 3.00 & \\
\hline & 4 & 30 & 8.73 & 2.79 & \\
\hline & 5 & 39 & 7.92 & 2.68 & \\
\hline & 6 & 23 & 8.91 & 2.70 & \\
\hline & 7 & 18 & 7.61 & 2.52 & \\
\hline & 8 & 22 & 7.59 & 2.02 & \\
\hline \multirow{7}{*}{$\begin{array}{l}\text { Domain 5: } \\
\text { Professional } \\
\text { training }\end{array}$} & 1 & 20 & 8.45 & 3.39 & \multirow{7}{*}{$<0.0001$} \\
\hline & 3 & 15 & 7.87 & 2.03 & \\
\hline & 4 & 30 & 10.93 & 3.74 & \\
\hline & 5 & 39 & 11.44 & 2.92 & \\
\hline & 6 & 23 & 12.09 & 2.84 & \\
\hline & 7 & 18 & 11.89 & 3.53 & \\
\hline & 8 & 22 & 11.36 & 2.92 & \\
\hline \multirow{7}{*}{$\begin{array}{l}\text { Domain 6: } \\
\text { Theoretical } \\
\text { activity }\end{array}$} & 1 & 20 & 8.95 & 2.96 & \multirow{7}{*}{0.0107} \\
\hline & 3 & 15 & 10.86 & 2.07 & \\
\hline & 4 & 30 & 8.93 & 2.89 & \\
\hline & 5 & 39 & 10.18 & 2.69 & \\
\hline & 6 & 23 & 10.65 & 2.84 & \\
\hline & 7 & 18 & 8.22 & 2.10 & \\
\hline & 8 & 22 & 9.36 & 2.22 & \\
\hline
\end{tabular}

Note: * $p$ value obtained through the Kruskal-Wallis test. Tables requested in relation to the PSQI of university students.

Table 4 - Classification for quality of sleep according to the Pittsburgh Sleep Quality Index questionnaire (PSQI), Natal, Rio Grande do Norte, Brazil, 2016

\begin{tabular}{|c|c|c|c|c|c|}
\hline \multirow{3}{*}{ Semester } & \multicolumn{4}{|c|}{ Pittsburgh Sleep Quality Index Classification } & \multirow{3}{*}{$p$ value* } \\
\hline & & & & & \\
\hline & $\mathbf{n}$ & $\%$ & $\mathbf{n}$ & $\%$ & \\
\hline 1 & 14 & 56.00 & 6 & 44.00 & \multirow{7}{*}{$<0,0001$} \\
\hline 3 & 9 & 60.00 & 6 & 40.00 & \\
\hline 4 & 8 & 26.66 & 22 & 73.33 & \\
\hline 5 & 39 & 100.00 & 0 & 0.00 & \\
\hline 6 & 5 & 21.74 & 18 & 78.26 & \\
\hline 7 & 18 & 100.00 & 0 & 0.00 & \\
\hline 8 & 15 & 68.18 & 7 & 31.81 & \\
\hline
\end{tabular}

Note: *p value obtained by the Chi-square test.

\section{DISCUSSION}

Most academics are women, characterizing nursing as a profession still exercised predominantly by women, although the number of men is increasingly growing, as observed in other studies $^{(13-15)}$. Other research results showed that most students are single and childless ${ }^{(16-17)}$.

Most students reported only studying and not performing work activities; however, in another study, the results were contrary, thus contrasting with this survey ${ }^{(17)}$. The higher number of students reported not engaging in physical activities, as perceived in another study; students stated that one of the causes for the sedentary lifestyle is the lack of time due to numerous curricular activities. However, this can lead to cardiovascular diseases, fatigue, sleep alterations, and implications for concentrating and even studying ${ }^{(18)}$.

Comparisons between stress levels and terms of the nursing program evidenced that the semesters in which students feel higher levels of stress, when compared with other terms, such as the fifth and eighth, whose level is moderate. The fifth semester is the first moment when students have many activities, attending nursing classes with extensive course load, and with lesser proximity of the professor in their practices, when compared with the previous semester. Therefore, they become more stressed and afraid of making mistakes ${ }^{(13-15)}$.

We perceived that students of the eighth semester had a moderate index, since beginning to provide nursing care, at this first moment when the student is at the hospital unit without the professor's monitoring, can be a stressor. On the other hand, when students feel very dependent on the professor who supervises them, and when the professor-student interaction does not take place, learning aspects are insufficient for them to feel motivated to learn and develop the basic techniques to attend the patient. In this regard, the first symptoms of the stress observed in this study may arise ${ }^{(13-14)}$.

These results, presented with moderate levels of stress, were also obtained from another study, pointing to the importance of paying attention to academic stress, since it may cause difficulties in academic activities, concentration to study, in addition to symptoms, such as anxiety, irritation, and a more serious problem such as the Burnout syndrome ${ }^{(1)}$.

In the analysis of data on domains of the AEEE instrument, we found that the domain on the performance of practical activities intended to performing procedures with the patients featured the higher average for the students of the sixth term. This can be observed when students directly face patients to perform an activity in the hospital reality, for example, a new place and with an unknown person. Thus, feelings of uncertainty and insecurity may arise in this situation ${ }^{(19)}$.

The association between students' levels of stress and the domains evidenced a statistically significant correlation when stress was related to practical activities. Students, when facing a new situation, for example, at the hospital and with critically ill patients in the intensive care unit, such as occurs in the sixth semester of the program, may have the feeling of not having learned what is required for the practice, of failing to achieve and externalize scientific and critical thinking, making them emotionally deprived ${ }^{(1)}$. 
In domain 2, concerning professional communication, students of the seventh term were those who obtained the highest average of stress. It is noteworthy that in this domain there are adversities in communication, in interpersonal relationships, and in other situations of conflicts that may arise. Statistically significant results evidence the correlation between stress and the students' difficulty regarding communicability and relationships when they are about to work as nursing professionals.

This must occur because most are young and feel insecure to approach professionals and patients, in addition to competitiveness to acquire knowledge and personal differences. The case should be widely debated in the classroom, exemplified in practical activities and, if necessary, develop coping strategies, since the nursing professional always works as a team and must know how to deal with such situation(6).

Domain 5, professional training, showed that students of the sixth semester obtained the highest average of stress. There was also a statistically significant correlation between stress and this domain. It was in this term and domain that students were more concerned about their academic education and the practices to be followed in the future.

Thus, we observed that, in order to minimize this level of stress and the feeling of insecurity, there is need of more laboratory practices, simulations, activities that bring the student closer to the nurses' work environment, thus decreasing anxiety, in such a way they understand that practice is not strictly technical knowledge, but the improvement of their skills acquired in the daily practice of nursing care ${ }^{(13)}$.

The dimension "theoretical activity," represented by domain 6, exposed students of the third semester as those with the highest average of stress. There was also a statistically significant correlation between stress and this domain. In the first three semesters of the program, we observed the amount of taught subjects and, hence, the exaggeration of programmatic contents and activities in the didactic method employed for nursing education. This requires the students' cognitive capacity and interest in studies and commitment, which can lead to stress ${ }^{(4,13)}$.

Most students manifested good sleep quality when compared with the terms when they were attending the undergraduate program (first, third, fifth, seventh, and eighth terms). Only in two semesters, fourth and sixth, they showed poor quality of sleep; the others were of good quality. These data were divergent from other studies, whose authors demonstrated a prevalence of poor sleep quality among respondents ${ }^{(4,20)}$.
Despite the quality of sleep influencing the level of stress of students, as perceived in another study, most participants of our research reported having good quality of sleep. Possibly, this is due to the distribution of their tasks, schedules, and longer time to sleep, in addition to a few of them having the need to perform another activity, such as work, which could alter the result ${ }^{(4)}$.

\section{Study limitations}

Although the contributions of this study are relevant to undergraduate students overall, they cannot be generalized, since we addressed a specific sample, undergraduate nursing students and from public universities; moreover, students of the second and ninth terms were not in the institution due to an internship, thus we could not collect data from this sample.

\section{Contributions to the fields of nursing, health, or public policies}

Our results contribute to nursing as an important indicator of the needs to rethink the education process of undergraduate students, seeking to invest in strategies to reduce stress that enable a healthier academic education, thereby benefiting the professional future.

\section{CONCLUSION}

Overall, we understood that students of the fifth and eighth semesters presented moderate levels of stress and, those of the sixth term, high level.

Quality of sleep was deemed good for the first, third, fifth, seventh, and eighth semesters; and poor for the fourth and sixth terms. Regarding the AEEE indices, students' stress regarding the performance of practical activities, professional communication, professional training, and theoretical activity showed a statistically significant correlation for the presence of stress.

Thus, we can rethink the teaching dynamics regarding the practices in healthcare units, aiming to bring them closer to patients and professionals, such as fostering activities focusing on interpersonal relationships, which give students more confidence, in such a way they can believe in their potential and in the power of the profession, having a less technicist perspective of the future.

Research is suggested with other methodological approaches and instruments that address all students of the program in order to broaden the research data and, therefore, recognize the inequalities of stress levels and the semesters of the program.

\section{REFERENCES}

1. Moreira DP, Furegato ARF. Stress and depression among students of the semester in two nursing courses. Rev Latino-Am Enfermagem. 2013;21(spe):155-62. doi: 10.1590/S0104-11692013000700020

2. Ferreira LRC, Martino MMF. Sleep patterns and fatigue of nursing students who work. Rev Esc Enferm USP. 2012;46(5):1176-81. doi: 10.1590/ S0080-62342012000500020

3. Araújo MFM, Lima ACS, Alencar AMPG, Araújo TM, Fragoso LVC, Damasceno MMC. Sleep quality assessment in college students from Fortaleza-CE. Texto Contexto Enferm. 2013;22(2):352-60. doi: 10.1590/S0104-07072013000200011

4. Benavente SBT, Silva RM, Higashi AB, Guido LA, Costa ALS. Influence of stress factors and socio-demographic characteristics on the sleep quality of nursing students. Rev Esc Enferm USP. 2014;48(3):512-8. doi: 10.1590/S0080-623420140000300018 
5. Fornés-Vives J, Garcia-Banda G, Frias-Navarro D, Rosales-Viladrich G. Coping, stress, and personality in Spanish nursing students: a longitudinal study. Nurse Educ Today. 2016;36:318-23. doi: 10.1016/j.nedt.2015.08.011

6. Soares MH, Oliveira FS. The relation between alcohol, tobacco and stress in nursing students. SMAD, Rev Eletrônica Saúde Mental Álcool Drog [Internet]. 2013 [cited 2017 Apr 12];9(2):88-94. Available from: http://pepsic.bvsalud.org/scielo. php?script=sci_abstract\&pid=S1806-69762013000200007\&lng=pt\&nrm=iso\&tlng=en

7. Paro CA, Bittencourt ZZLC. Qualidade de vida de graduandos da área da saúde. Rev Bras Educ Med. 2013;37(3):365-75. doi: 10.1590/ S0100-55022013000300009

8. Ministério da Saúde (BR). Resolução n 466, de 12 de dezembro de 2012. [Internet]. Brasília: Ministério da Saúde; 2012 [cited 2016 June 15]. Available from: http://bvsms.saude.gov.br/bvs/saudelegis/cns/2013/res0466_12_12_2012.html

9. Buysse DJ, Reynolds CF, Monk TH, Berman SR, Kupfer DJ. The Pittsburg sleep quality index: a new instrument for psychiatric practice and research. Psychiatry Res. 1989;28(2):193-213. doi: 10.1016/0165-1781(89)90047-4

10. Carpenter JS, Andrykowski MA. Psychometric evaluation of the Pittsburg sleep quality index. J Psychosom Res. 1998;45(1):5-13. doi: 10.1016/S0022-3999(97)00298-5

11. Bertolazi AN. Tradução, adaptação cultural e validação do sono: escala de sonolência de Epworth e índice de qualidade de sono Pittsburgh [Dissertação] [Internet]. Porto Alegre: Universidade Federal do Rio Grande do Sul; 2008 [cited 2016 Sep 22]. Available from: https://lume. ufrgs.br/handle/10183/14041

12. Costa ALS, Polak C. Construction and validation of an instrument for the assessment of stress among nursing students. Rev EsC Enferm USP. 2009;43(spe):1017-26. doi: 10.1590/S0080-62342009000500005

13. Costa MAR, Oliveira JLC, Souza VS, Inoue KC, Reis GAX, Matsuda LM. The association between stress and sociodemographic variable on nursing student of an institution in Paraná. Rev Enferm UFJF [Internet]. 2016 [cited 2017 Jun 02];2(1):9-19. Available from: https://periodicos. ufj.br/index.php/enfermagem/article/view/3837

14. Cestari VRF, Barbosa IV, Florêncio RS, Pessoa VLMP, Moreira TMM. Stress in nursing students: study on sociodemographic and academic vulnerabilities. Acta Paul Enferm. 2017;30(2):190-6. doi: 10.1590/1982-0194201700029

15. Bagcivan G, Cinar FI, Tosun N, Korkmaz R. Determination of nursing students' expectations for faculty members and perceived stressors during their education. Contemp Nurse. 2015;50(1):58-71. doi: 10.1080/10376178.2015.1010259

16. Preto VA, Garcia VP, Araujo LG, Flauzino MM, Teixeira CC, Parmegiane RS, et al. Perception of stress in nursing academics. Rev Enferm UFPE. 2018;12(3):708-15. doi: 10.5205/1981-8963-v12i3a230940p129-139-2018

17. Dias AL, Hoepers NJ, Poluceno GAS, Ceretta LB, Schwalm MT, Soratto MT. Ocorrência de estresse entre acadêmicos de enfermagem de um curso noturno. Rev Saúde.com [Internet]. 2014 [cited 2015 Aug 25];10(2):129-39. Available from: http://periodicos2.uesb.br/index.php/rsc/ article/view/294

18. Hirsch CD, Barlem EL, Tomaschewski-Barlem JG, Lunardi VL, Oliveira ACC. Predictors of stress and coping strategies adopted by nursing students. Acta Paul Enferm. 2015;28(3):224-9. doi: 10.1590/1982-0194201500038

19. Lazarus RS, Folkman S. Stress, appraisal and coping. New York: Springer; 1984.

20. Santos TCMM, Martino MMF, Sonati JG, Faria AL, Nascimento EFA. Sleep quality and chronotype of nursing students. Acta Paul Enferm. 2016;29(6):658-63. doi: 10.1590/1982-0194201600092 